\title{
Hoe algemeen is de algemene economie?
}

\author{
Citation for published version (APA):
}

Muysken, J. (1985). Hoe algemeen is de algemene economie? Van Gorcum. https://doi.org/10.26481/spe.19850906jm

Document status and date:

Published: 06/09/1985

DOI:

10.26481/spe.19850906jm

Document Version:

Publisher's PDF, also known as Version of record

\section{Please check the document version of this publication:}

- A submitted manuscript is the version of the article upon submission and before peer-review. There can be important differences between the submitted version and the official published version of record.

People interested in the research are advised to contact the author for the final version of the publication, or visit the DOI to the publisher's website.

- The final author version and the galley proof are versions of the publication after peer review.

- The final published version features the final layout of the paper including the volume, issue and page numbers.

Link to publication

\footnotetext{
General rights rights.

- You may freely distribute the URL identifying the publication in the public portal. please follow below link for the End User Agreement:

www.umlib.nl/taverne-license

Take down policy

If you believe that this document breaches copyright please contact us at:

repository@maastrichtuniversity.nl

providing details and we will investigate your claim.
}

Copyright and moral rights for the publications made accessible in the public portal are retained by the authors and/or other copyright owners and it is a condition of accessing publications that users recognise and abide by the legal requirements associated with these

- Users may download and print one copy of any publication from the public portal for the purpose of private study or research.

- You may not further distribute the material or use it for any profit-making activity or commercial gain

If the publication is distributed under the terms of Article $25 \mathrm{fa}$ of the Dutch Copyright Act, indicated by the "Taverne" license above, 


\title{
HOE ALGEMEEN IS DE ALGEMENE ECONOMIE?
}

\author{
REDE \\ in verkorte vorm uitgesproken bij de aanvaarding van het \\ ambt van hoogleraar in de Algemene \\ economie aan de Rijksuniversiteit \\ Limburg \\ op vrijdag 6 september 1985 \\ door \\ Dr. J. Muysken
}



Van Gorcum, Assen/Maastricht, 1985 



\title{
HOE ALGEMEEN IS DE ALGEMENE ECONOMIE?
}

\author{
Prof. dr. J. Muysken
}

\section{Inleiding}

In hoeverre is een zinvolle micro-economische onderbouwing van de macro-economie mogelijk en in welke mate en op welke wijze kan de notie van een representatief economisch subject daarbij dienstig zijn? Door deze vraagstelling te kiezen voor mijn betoog hoop ik die mensen te antwoorden die mij lichtelijk geamuseerd vroegen of ik de zoveelste persoon ben die zonodig zijn vakgebied moet afbakenen en uitleggen voor een breed publiek. Nu lijkt dat mij overigens wel de bedoeling van een orallie en ik wil daaraan zeker tegemoetkomen. De reden daarvoor ligt niet alleen in het volgen van een goed gebruik, maar deze oratie is én van de eerste twee oraties die worden gehouden aan de Faculteit der Economische Wetenschappen van de Rijksuniversiteit Limburg. Een faculteit die zich onder meer onderscheidt van haar zusterfaculteiten in den lande doordat wordt gestreefd naar een grote mate van samenwerking tussen de algemene en de bedrijfseconomie. Het mag u dan niet verbazen dat Hein Schreuder en ik in onze oraties trachten een plaatsbepaling te geven van de algemene en de bedrijfseconomie en daarbij proberen terreinen in kaart te brengen waarop vruchtbaar kan worden samengewerkt. Ik zal dit doen voor de algemene economie aan de hand van de hierboven geformuleerde vraagstelling die ik nu zal toelichten.

Stel, dat er een artikel zou zijn geschreven met als titel 'A Micromacroeconomic Analysis Based on a Representative Firm': een micro- en macro-economische analyse die gebaseerd is op het gedrag wan een representatieve onderneming. Een dergelijk artikel zou de twee belangrijkste vakgebieden binnen de algemene economie, namelijk de micro-economie en de macro-economie, bij elkaar brengen. En het is juist de relatie tussen deze wee wakgebieden waarop ik nader in wil gaan. Ik vraag mij namelijk af of de algemene economie zo algemeen is dat de micro- en de macroeconomie consistent in één analyse kunnen worden verwerkt. Anders geformuleerd, is een goede micro-economische onderbouwing van de macro-economie mogelijk? Daamaast vraag ik me af of een dergelijk artikel 
niet een prachtige basis zou bieden voor een samenwerking tussen de algemene en de bedrijfseconomie. Uitgangspunt voor de analyse zou immers de representatieve onderneming zijn.

U zult al wermoeden dat er inderdaad een artikel bestaat met de titel 'A Micro-macroeconomic Analysis Based on a Representative Firm". Ik noem dit artikel omdat het geschreven is door een representatieve algemeen-econoom: de aanpak ervan is kenmerkend voor de algemeen-economische benadering. Nu is het wellicht gevaarlijk om te spreken van 'de' algemeen-economische benadering. Men kan immers binnen de algemene economie verschillende benaderingen onderscheiden, die tot soms nogal drastische verschillen in conclusies kunnen leiden. Ik kom daar straks op terug.

Waar het mij nu om gaat is dat als het gevaarlijk is om over 'de' algemene economie te spreken, het onduidelijk is wat men zich nog moet voorstellen bij een representatieve algemeen-econoom. Dit moge u wat eenvoudig in de oren klinken, maar wat stelt u zich voor bij het begrip representatieve onderneming? Want hoezeer men het begrip representatief algemeeneconoon ook zou willen relativeren, het is binnen de algemene economie een zeer wijd verbreid gebruik om te spreken over een representatieve onderneming, of in meer algemene zin een 'representatief' economisch subject. Bij de vraagstelling van dit betoog wil ik mij ook richten op dit gebruik. De vraag is dan op welke wijze en in welke mate de notie van een representatief economisch subject dienstig kan zijn bij een micro-economische onderbouwing van de macro-economie.

\section{Het representatieve economische subject: Marshall en Hicks}

Het begrip representatieve onderneming ('representative lirm') is rond de eeuwwisseling geintroduceerd door Alfred Marshall. ${ }^{2}$ Marshall hanteert het begrip bij de bespreking van de factoren die de normale kostprijs van een goed bepalen. Belangrijk voor deze kostprijs is de produktie-omvang, zowel van de onderneming zelf (intern) als van de totale industrie (extern). Hij stelt dan: '...een representatieve onderneming is in zekere zin een gemiddelde onderneming. Maar er zijn vele manieren waarop het begrip 'gemiddelde' kan worden geinterpreteerd in relatie tot een bedrijf. En een representatieve onderneming is die bijzondere soort gemiddelde onderneming waarnaar we moeten kijken om te zien in hoeverre de schaaleffecten

\footnotetext{
I Zic Ng (1982). Alle citaten wan buttenlandse auteurs in deze oratie zijn door mijzelf vertaald.
}

2 Zie Marshall (1949). 
van produktie, zowel intern als extern, in een bepaade industrie en land zijn voortgeschreden. Wij kunnen dit niet zien door nar een of twee willekeurig gekozen ondernemingen te kijken. Maar wij kunnen dit tamelijk goed bekijken door, na uitvoerig rond te schouwen, een onderneming ... uit te kiezen (of beter nog, meer dan een), die naar ons beste weten dit bijzondere gemiddelde vertegenwoordigt'. Ik citeer Marshall letterlijk ondat in zijn omschrijving een belangwekkend element zit dat men later niet meer tegenkomt bij het hanteren van het begrip representatief. Dit betreft de notie dat men een representatief economisch subject, om het begrip te generaliseren, ook daadwerkelijk moet kunnen waarnemen.

Het is echter, zoals gesteld, zeer gebruikelijk om bimnen de algennene economie te spreken over het gedrag van dé consument of dé producent. Men doelt dan echter op statistische gemiddelden van groepen. Een mooi voorbeeld treft men aan bij Hicks, als hij de theorie van het consumentengedrag uiteenzet. Hij komt dan tot uitspraken over het gedrag van een consument en stelt dat de theorie: "... is gepresenteerd - zoals die ook moet worden gepresenteerd - als een middel waarmee we soms kunnen vertellen of het gedrag van een bepalde consument wel of niet consistent was met de veronderstelling dat hij handelde in overeenstemming met een onveranderde woorkeursordening'. Het beschikbare statistisch materiaal heeft echter betrekking op groepen consumenten. Maar dit is ook alleen het soort materiaal dat Hicks wil gebruiken om zijn theorie te toetsen. Immers, de theorie: "...krijgt alleen een prima facie plausibiliteit als zij wordt toegepast op een statistisch gemiddelde. De veronderstelling dat de representatieve consument zich gedraagt als een ideale consument is een hypothese die de moeite waard is om te toetsen; de veronderstelling dat een bepaalde persoon, de heer Pietersen of de heer Jansen die om de hoek woont, feitelijk zo handelt verdient geen ogenblik ook maar enige aandacht" . $\mathrm{U}$ ziet dat het representatieve economische subject hier niet een zorgvuldig geselecteerd aanwijsbaar individu is, maar een abstract gemiddelde.

In het vervolg zal ik de eerste opvatting kenschetsen als de Marshalliaanse opvatting en de tweede opvatting als de Hicksiaanse opvatting. Het is daarbij niet mijn bedoeling om deze opvattingen strikt toe te schrijven aan Marshall danwel Hicks. Zo zou men bijv. de Marshalliaanse opvatting kunnen interpreteren alsof men alle uitspraken over het producentengedrag of consumentengedrag zou moeten kunnen waarnemen bij aanwijs-

3 Marshall (1949), p. 265.

4 Hicks (1956), pp. 54-55 
bare personen of instellingen. Dit gaat echter veel verder dan Marshall zou willen. ${ }^{5}$

In de ontwikkeling van de economische theorie en het empirisch onderzoek na de Tweede Wereldoorlog is de Hicksiaanse opvatting dominant aanwezig, in combinatie met de axiomatisch-deductieve methode. Op basis van sterke a priori noties formuleert men veronderstellingen over het gedrag van het representatieve subject die niet voor enig individu behoeven te kunnen worden waargenomen. Confrontatie met de empirie van voorspellingen die op grond van deze hypothesen worden afgeleid, moeten dan uitsluitsel geven in hoeverre de veronderstellingen bruikbaar zijn voor verdere theorievorming. Dit betekent overigens niet dat men zomaar allerlei veronderstellingen kan uitproberen, in een soort blind instrumentalisme. ${ }^{6}$

Men kan de aldus geschetste Hicksiaanse benadering stellen tegenover een Marshalliaanse benadering waarbij men poogt door zorgvuldige waarneming te komen tot generalisaties, maar wel op een zodanige wijze dat de veronderstellingen waartoe deze generalisaties leiden, herkenbaar blijwen in relatie tot het waarnemingsmateriaal. Ik kom hier later op terug. Eerst wil ik u echter laten zien hoe de Hicksiaanse benadering in de na-oorlogse theorievorming en empirisch onderzoek is toegepast.

\section{De Hicksiaanse benadering}

Het lijkt mij aardig om bij de vraag waar de Hicksiaanse benadering toe heeft geleid, aan te sluiten bij het oorspronkelijke citaat van Hicks dat betrekking heeft op de micro-economische theorie van het consumentengedrag. Hicks stelt dat de veronderstelling 'dat de representatieve consument zich gedraagt als een idealle consument' een hypothese is, die "de moeite waard is om te toetsen". Hoe wordt nu een dergelijke weronderstelling getoetst?

Zo stelt Marshall bijv, ook: Economisten bestuderen de handelingen wan individuen, mar zij bestuderen deze erder in relatic to het matschappelijke dan het individuele leven, en drarom louden zij zichzelf maar weinig bezig met persoonlijke bijzonderheden die iemands stemming of karakter betreffen ... Zij shan zorguldig het gedrag var een grote groep personen gade ... : en met behulp van statistieken, of anderszins, stellen zij wast hoeveel geld gemiddeld de leden van de growp, die zij gadeslaan, net willen betalen als de prijs van wen bepaald goed... Hierbij gaan zij echter om met de mens zoals hij is: niet met ean abstract of "economisch" mens: maar een mens wan vlees en bloed" (Marshall 1949, pp. 21-22).

"Het instrumentalisime, warbij men alleen naar de 'voorspellende' warde wan een theoric kijkt - voor een beschrijving, zie bijv. Blaug (1980), pp. 104 c.v. - vind nauwelijks nog weerklank binnen de economische wetenschap. Dit blijk bijv. uit thet citaat van Grossman in noot 28. 
Aan deze vraag is binnen micromeconomische theorie erg veel aandacht besteed. "Globaal komt het er op neer dat men het gedrag van de representatieve consument afleest uit de manier warop deze vrag uitoefent naai bepaalde goederen. Hierbij wordt ervan uitgegaan dat de representatieve consument zijn nut afhankelijk stelt van het bezit van een aantal goederen en ernaar streeft zijn gegeven inkomen zodamig te besteden dat hij zijn nut maximaliseert. Men kan dan voor de representatieve consument voor ieder van deze goederen een vraagfunctie afleiden, waarbij de vraag naar ieder goed afhankelijk is van de prijzen van alle goederen en het inkomen. Daarbij leidt de veronderstelling dat het nut wordt gemaximaliseerd tot bepaalde eisen aan de eigenschappen van de vraagfuncties. Welnu, als men beschikt over waarnemingen over de vraag naar de goederen, de prijzen van deze goederen en het inkomen, kan men de vraagfuncties schatten, als men ervan uitgaat dat de voorkeuren van de representatieve consument niet veranderen in de loop van de tijd. ${ }^{8}$ Het toetsen van de vraagtheorie betekent dan dat men nagaat of de waargenomen vraagfuncties inderdaad eigenschappen hebben die consistent zijn met de veronderstelde eigenschappen van de nutsfuncties en het veronderstelde nuts-maximaliserende gedrag."

Maar, zoals Hicks al stelde, het beschikbare statistisch material heeft alleen betrekking op groepen consumenten - en dat is ook alleen maar interessant. Het is daarom ook zeer gebruikelijk om de hierboven beschreven vraaganalyse toe te passen op de consumptieve bestedingen aan een aantal goederencategorieën per hoofd van de bevolking in een bepaald land. Hierbij kan dit aantal oplopen van 3 tot pakweg 40 of desnoods 120 goederencategorieèn. ${ }^{10}$

Ik kan mij voorstellen dat $u$ een gevoel van onbehagen bekruipt als u met een dergelijke analyse wordt geconfronteerd. Maar waarin schuilt dan dat onbehagen? Wordt het weggenomen als bepaalde vraagvergelijkingen, die zijn afgeleid op de hierboven geschetste wijze, herhaaldelijk worden geschat voor een grote steekproef van consumenten voor wat betreft hum uitgawen aan een groot aantal goederen? Wat zoudt u concluderen als dan

\footnotetext{
"Men denke bijw aan hel pionierswerk van Barten (1964) en al het werk dat daarop is gevolgd. Voor een samenvatting zie Barten (1977).

Strikt gesproken beschikt men niet over waarnemingen van de vragg mar goederen "mat van de verhandelde hoeveetheid goederen.

9 Men kan zich aftijd bij strijdigheid van de theorie met waarnemingen afvragen of wel aan de veronderstelle voonwaarden (bijv. dat voorkeuren miet veramderen in de loop van de tijd) is voldaan. Voor een boeiende bespreking wan de stelling van Duhem en Quine oxet dit methodologische probteem leze men Cross (1982).

10 Zie bijv. Deaton (1975).
} 
bij voortduring wordt gevonden dat de eigenschappen wan deze vergelijkingen voldoen aan de door de theorie gestelde eisen? Het lijkt mij dat u dan kunt concluderen dat de consumenten zich gemiddeld genomen gedragen in overeenstemming met het gedrag van de representatieve consument. Dit betekent duidelijk niet dat ook maar één consument zich precies zo hoeft te gedragen als de representatieve consument. Maar als thet dat niet hoeft te betekenen, warom kan men dan niet de analyse toepassen voor de totale uitgaven wan consumenten aan verschillende groepen van goederen in een bepaalde periode in een bepaald land? Immers, de geenqueteerde consumenten vormen een steekproef uit de totale consumentenpopulatie. En het onderzoek richt zich met behulp van deze steekproef op het gedrag van de totale populatie. Maar daamee richt het zich ook op de totale consumptieve bestedingen naar bepaalde goederen die in een land worden gedaan.

Men ziet hoe op deze wijze de Hicksiaanse benadering in het huidige micromeconomisch onderzoek herkenbaar is. Op basis van sterke a priori noties wordt voor de representatieve consument een nuts-maximaliserend gedrag verondersteld en worden hypothesen afgeleid met betrekking tot diens vraag naar goederen. De representatieve consument wordt daarbij gezien als het gemiddelde van de totale consumentenpopulatie, of van een steekproef daaruit. "De hypothesen worden dan ook getoetst op basis van gegevens die betrekking hebben op een heel land, of vergelijkbare gegevens.

Het hierboven gegeven voorbeeld is overigens kenmerkend voor de manier van onderzoek bedrijven binnen de gehele micro-economie. ${ }^{12}$

\section{Het reductionisme}

De hierboven geschetste onderzoektraditie is naar mijn mening evenzeer kenmerkend voor een belangrijke stroming binnen de economische theorie die Coddington reductionisme heeft genoemd: 'Ruwweg gezegd bestond de methode (van deze stroming, J.M.) uit het analyseren van markten op basis van de keuzen die door individuele handelaren worden gemaakt. Op deze wijze beweegt de theorie zich op twee verschillende niveaus - dat van de individuele keuze, en dat wan marktverschijnselen - ofschoon de verbinding tussen beide niveaus misschien alleen kan worden gelegd door de keuze van een 'representatieve' handelaar te bestuderen. Voorts moet, teneinde en

\footnotetext{
"Immers, de theorie "...krigt alleen prima facie plausibiliteit als zij wordt toegepast op een statistisch gemiddelde" (zie noot 4).

12 In de theorie van het producentengedrag wordt bijw. voot de representatieve ondernemer een winstmaximaliserend of kostenminimaliserend gedrag verondersteld. Daamee worden vervolgens hypothesen afgeleid voor de vraag nar produktiemiddelen, die worden getoetst aan de hand van geaggrageerde gegevens.
} 
basis te verschaffen voor een hanteerbare analyse van de marktverschijnselen, de analyse van individuele keuze bijzonder stereotype en kunstmatig zijn ... de centrale gedachte is de reductie van marktverschijnselen tot (gestileerde) individuele keuzen ". ${ }^{3}$ andaar ook de naam reductionisme.

U herkent hopelijk het hierboven gegeven voorbeeld in deze omschrijving. In de theorie van het consumentengedrag wordt de vaagfunctie van de representatieve consument naar een bepaald goed afgeleid door ervan uit te gaan dat deze zijn nut tracht te maximaliseren onder bepaalde nevenvoorwaarden. De vraagfunctie naar dat goed die op deze wijze is afgeleid, wordt vervolgens geïdentificeerd met de vraagcurve op de markt voor dat goed. De markt-vraagcurve wordt op deze wijze gereduceerd tot de vraagfunctie van de representatieve consument. Op analoge wijze wordt volgens de Hicksiaanse benadering de aanbodcurve van dat goed op die markt afgeleid door te veronderstellen dat de representatieve ondernemer streeft naar maximale winst of minimale kosten onder bepaalde nevenvoorwaarden. De marktevenwichtprijs kan dan worden bepaald op het snijpunt van vraag- en aanbodcurve. ${ }^{14}$

Deze gedachte is terug te vinden in de algemene evenwichtstheorie, waarin alle markten in een volkshuishouding in onderlinge samenhang worden geanalyseerd. Aan deze theorie zal altijd de naam van Walras verbonden blijven. Weintraub heeft onlangs de algemene evenwichtstheorie in Lakatosiaanse termen beschreven als een neo-Walrasiaans onderzoekprogramma. ${ }^{15}$ De harde kern van dit programma, dat wil zeggen de verzameling van elementen uit de algemene evenwichtstheorie die niet vruchtbaar ter discussie kunnen worden gesteld, bevat volgens Weintraub de volgende uitgangspunten: ${ }^{16}$

- economische personen kunnen keuzemogelijkheden naar voorkeur rangschikken;

- personen optimaliseren individueel onder bepaalde nevenvoorwarden;

- het keuzegedrag van personen uit zich op onderling samenhangende markten;

- personen beschikken over volledige relevante kennis;

- waarneembare gebeurtenissen op markten vertonen samenhangen, en moeten worden besproken met betrekking tot evenwichtssituaties.

13 Coddington (1983), pp. 92.93.

14 Voor en nuancering van dit punt, zie Snippe (1985a), par. 2.4.1.

15 Weintraub (1985).

16. Weintraub (1985), p. 147. 
Waar hierboven word" gesproken van "personen" gebruikt Weintraub het onvertaalbare woord "agent". Men herkent direct in de personen of "agents" de Hicksiaanse representatieve conomische subjecten waarvan het individuele keuzegedrag in Coddingston's woorden 'bijzonder stereotype en kunstmatig' is. Coddington's beschrijving van het reductionisme geldt dan ook duidelijk voor de neo-Walrasiaanse algemene evenwichtstheorie. ${ }^{\text {? }}$

Met het bovenstaande beoog ik aan te geven dat de dominante traditie van de Hicksiaanse benadering in het micro-economisch onderzoek na de Tweede Wereldoorlog, heeft geleid tot het reductionisme. Het onderzoek binnen de micro-economie wordt gekenmerkt doordat voor personen (agents) wordt verondersteld dat zij hun keuzemogelijkheden naar voorkeur kunnen rangschikken. Zij bepalen dan hun keuzen door te optimaliseren onder nevenwoorwaarden, waarbij zij over volledige relevante informatie beschikken. "ik $\mathrm{zal}$ dit uitgangspunt in het vervolg aanduiden als het keuzetheoretische uitgangspunt. Kenmerkend voor de Hicksiaanse benadering is dat dit keuzetheoretische uitgangspunt wordt toegepast op een Hicksiaans representatief subject. Immers, alleen de veronderstelling dat het representatieve subject handelt volgens het keuzetheoretische uitgangspunt is een hypothese die de moeite waard is om te toetsen. Maar daardoor leidt de Hicksiaanse benadering ook precies tot het reductionisme: de verbinding tussen individuele keuze en marktverschijnselen wordt alleen gelegd door de representatieve handelaar.

\section{De macro-economische benadering}

Hoe moet deze ontwikkeling nu worden beoordeeld? Moet de ontwikkeling van een belangrijk deel van het economisch onderzoek in de richting van het reductionisme worden betreurd of toegejuicht? Het is verstandig om zich bij de beantwoording van deze vraag te realiseren dat Coddington het reductionisme introduceert om: '...de methode van analyse te karakteriseren van dat theoretisch bouwwerk waartegenover Keynes zijn eigen theorie stelde. ${ }^{19}$ Kan de Keynesiaanse theorie dan worden beschouwd als een alternatief voor het reductionisme?

U zult al aamwoelen dat dó Keynesiaanse theorie tegenover hẻt reductio-

" Coddington (1983), p.93. Coddington stelt echter uitdrukkelijk: ".. deze betrokkenheid op marktewernicht is nief den definiendende kakteristiek wan het reductonisme: het is eender een manior at ap de reductionistische theorievorming hanteerbaar kon worden gehouden. "Is In de zgu. tijdelijke venwichtsbendering wordt er niet van uitgegaan dat deze informatie achteral juist blijkt te zijn: aan het begin wan de Hicksaanse week nemen subjecten beslissingen op grond wan verwachtingen die soms an het einde van die week niet uit bligken te komen. Zij herzien dan bun varwachtingen en baseren daarop hun beslissingen aan het begin van de volgende week.

(19) Coddington (1983), p. 92 . 
nisme stellen op zich complicaties oproept die juist het onderwerp zinn van dit betoog: Wat is dé Keynesiaanse theorie? Zoals bij de meeste beroemde auteurs het geval is, leent het werk van Keynes zich voor meerdere interpretaties - hetgeen dan ook regelmatig aanleiding geeft tot geschriften met titels als: Was Keynes een echte Keynesiaan? In navolging van Coddington onderscheid ik drie varianten van het Keynesianisme, die elkaar deels aanvullen. In eerste instantie wil ik daarbij ingan op de meeste bekende versie van de Keynesiaanse theorie die door Coddington hydratlicisme wordt genoemd. ${ }^{20}$

Het hydraulicisme is de weergave van de Keynesiaanse theorie zoals die werd en wordt gepresenteerd in de leerboeken die na de Tweede Wereldoorlog zijn verschenen. De economie wordt bestudeerd op geaggregeerd. niveau, waarbij maar enkele markten worden onderscheiden. Goederenstromen als het nationaal produkt en arbeidsstromen als de werkgelegenheid zijn homogeen samengesteld. Er wordt binnen deze stromen geen onderscheid gemaakt tussen prijzen en hoeveelheden. Essentieel voor het hydraulicisme is dat er stabiele relaties worden verondersteld tussen verschillende geaggregeerde stromen - het geaggregeerde prijspeil, de loonvoet en de interestwoet kunnen eventueel ook nog een rol spelen. Een typisch Keynesiaanse relatie is bijv. de consumptiefunctie waarbij de consumptieve bestedingen in een land worden verondersteld in een stabiel, min of meer lineair verband te staan tot het nationale inkomen van dat land. Deze relatie ligt ten grondslag aan de typisch Keynesiaanse notie varn de inkomens-vermenigvuldiger. En het is dankzij het stabiele karakter van de geaggregeerde verbanden dat de overheid in staat is een economie te beinvloeden. ${ }^{21}$

Het is duidelijk dat in deze worm de Keynesiaanse theorie haaks staat op het reductionisme. Immers als bij het redeneren in termen van geaggregeerde stromen geen duidelijk onderscheid wordt gemaakt tussen prijzen en hoeveelheden, kunnen prijzen nooit die intermediërende rol spelen op markten, die centraal staat bij het reductionisme. Door de werking van het prijsmechanisme op markten waarover wordt geaggregeerd te negeren, worden allocatieproblemen en werkgelegenheidsproblemen losgekoppeld. ${ }^{22 .} 23$

De eerste serieuze tegenstanders van het Keynesiaanse hydraulicisme

213 Coddington (1983), pp. 102-103.

21 Zie Coddingron (1983), p. 103.

22 Coddington (1983), pp. 103 en 111

2 Hier zijn tevens enkele opmerkingen over het onderscheid tussen micro- an macromeconomie op hun plaats. Ondat dit echter het betoog te veel natar een ziyspoor stuurt, heb ik mijn visie op dit anderscheid als bijlage opgenomen. 
waren de monetaristen. Een wan de boeiende aspecten wan het monetarisme in dit verband is dat, alhoewel het sterk georiènteerd is op het keuzetheoretische paradigma, het in wezen ook een hydraulische benadering is. Ook in deze theorie spelen stabiele relaties tussen geaggregeerde grootheden een belangrijke rol. Dit komt bijv. tot uitdrukking in de neokwantiteitstheorie, walarin een stabiele relatie wordt verondersteld tussen de maatschappelijke geldhoeveelheden en het geaggregeerde prijspeil. ${ }^{2}$ Modigliani ging in 1977 zelfs zover dat hij stelt dat: 'De aanval van de monetaristen op de Keynesianen betrof vanaf het eerste begin niet de Keynesiaanse gedachtengang als zodanig ... Zij berustte op een totaal verschillende empirische beoordeling van de parameters ... En deze verschillende beoordeling rechtvaardigde op haar beurt een radicale afwijzing van de praktische relevantie van de Keynesiaanse gedachtengang in tegenstelling tot de analytische betekenis ervan". ${ }^{25}$ In die zin kan men ook de uitspraak begrijpen die aan de lleidende monetarist Friedman wordt toegeschreven: "Wij zijn nu allemaal Keynesianen". ${ }^{2 t}$

Dit is echter een vertekend beeld van de tegenstelling tussen Keynesianen en monetaristen. Modigliani zegt biju. in hetzelfde artikel: "Nietmonetaristen accepteren wat ik als de wezenlijke praktische boodschap van de General Theory beschouw: dat een vrije markteconomie die gebruik maakt van onstoffelijk geld stabilisatie nodig heeft, $\mathrm{kan}$ worden gestabiliseerd en derhalve moet worden gestabiliseerd door geschikte monetaire en financiële overheidspolitiek. Monetaristen nemen daarentegen het standpunt in dat het niet echt nodig is om de economie te stabiliseren; dat zelfs als het nodig zou zijn, het niet mogelijk is, want stabilisatiepolitiek zal waarschijnlijk de instabiliteit eerder vergroten dan verkleinen... ${ }^{2 \gamma}$ Welnu, het verschil in visie dat hier wordt geschetst op het functioneren van een markteconomie gaat veel verder dan verschillen in opvattingen over de waarden van de parameters in een Keynesiaans analytisch kader. Dit besef is echter pas in de loop van de tijd gegroeid.

Een belangrijk probleem bij het debat tussen monetaristen en Keynesianen is dat, zelfs voor zover men het meningsverschil wil reduceren tot verschillende opvattingen over parameterwaarden, men er niet in slaagde om het eens te worden over de relevante feiten. Beide partijen nemen de werkelijkheid op hun eigen manier waar en komen dan tot radicaal verschillende conclusies. En het is mede dit onvermogen om de waargenomen

24 Een stijging van de matschappelijke geldvoorrad zal darom altijd leiden to infatie.

2. Modiglani (1977), p. 23. Ook Tobin stelt: Het meningswerschil tussen monetaristen en Keynesianen ging over de warden van sommige parameters.' In: Klamer (1984), p. 106.

26 Modigliani (1977), p. 114.

2. Mlodigliani (1977), p. 114 
werkelijkheid te laten beslissen wie er gelijk heeft, dat aan de verdere theorievorming een boeiende wending heeft gegeven. Men ging namelijk proberen om het bestaan wan de stabiele geaggregeerde relaties te verklaren vanuit het keuzetheoretische paradigma ${ }^{23}$; dit zou dan tevens kumen aangeven onder welke omstandigheden de geaggregeerde relaties zich als stabiele relaties voordoen. ${ }^{26}$ Het spreekt haast vanzelf dat de monetaristen en de Keynesianen hierbij elk een verschillende weg insloegen. De Keynesiaans geinspireerde richting is die van de algemene onevenwichtigheidsanalyse, de monetaristisch geinspireerde richring is die van de NieuwKlassieke analyse, waarin de theorie van de rationele verwachtingen een belangrijke rol speelt.

\section{De micro-economische onderbouwing}

Het is opmerkelijk dat zowel de Nieuw-Klassieke analyse als de onevenwichtigheidsanalyse uitgaan van een representatief economisch subject dat handelt volgens het keuzetheoretisch uitgangspunt in de hierboven omschreven zin. Een belangrijk verschil in inzicht tussen beide benaderingen betreft echter de mate waarin het representatieve subject geïnformeerd is over in hoeverre prijzen waarmee hij wordt geconfronteerd Walrasiaanse evenwichtsprijzen zijn. Hiermee hangt samen een visie op de snelheid waarmee prijzen zich aampassen aan marktomstandigheden.

In de Nieuw-Klassieke denkwijze wordt er van uitgegaan dat de subjecten rationele verwachtingen hebben en dat het prijsmechanisme sterk werkt in de richting van Walrasiaans evenwicht. ${ }^{30}$ Wel worden de subjecten gehinderd door beperkte informatie en onzekerheid: zij weten namelijk niet direct of een prijsverandering op een bepaalde markt toe te schrijven is aan locale omstandigheden, dan well een verandering in het algemeen prijsniveau weerspiegelt. Maar deze onduidelijkheid wordt verondersteld snel te worden opgelost. Afgezien van toevallige verstoringen zullen representatieve subjecten dan juiste verwachtingen hebben omtrent de even-

28 Zoals Grossman (1979, p. 64) stelt: "In recente jaren 2 in de theoretische modellen van nacro-economische relaties niet alleen beoordedd naar de mate warin zij overenstemmen met wargenomen verschijnselen, mar ook nar hun gebruik van overtuigende keuzetheoretische onderbouwingen voor het onderliggende gedrag van individuen". Zie ook Kimer $(1984$, pp. 4-5).

2 Zie Coddington (1983), p. 109. Cross (1982) demonstreen echter overtugend dat de stabiliteit van een macto-economische relatie alleen kan worden beoordee dd in confunctie met vele aanwillende hypothesen.

30 Voor een boeiend overzicht wan deze denkwijze, zie Klamer (1984). Men realisere zich dat de" Nieuw-Klassieke denkwijze uitgatat wan twee belangrike veronderstellingen: de veronder. stelling wan de rationele verwachtingen en de weronderstelling dat het conomische proces sterk naar evenwicht tendeert. 
wichtsprijzen en handelen in overeenstemming met marktevenwicht. Dit leidt tot een stabiele evenwichtige macro-economische ontwikkeling, warin conjuncturele fluctuaties optreden als gevolg van de toevallige verstoringen. Voorts geldt dat als de subjecten juiste verwachtingen koesteren, overheidsoptreden in een economie weinig zin zal hebben - hoogstens als stoorzender - omdat de effecten ervan dankzij de goede werking van het marktmechanisme worden doorzien.

Hiertegenover staat de Keynesiaans geïnspireerde onevenwichtigheidsanalyse, waarin er vanuit wordt gegaan dat prijzen zich slechts langzaam aanpassen aan marktomstandigheden. Bovendien zijn de representatieve subjecten slecht geinformeerd over de marktomstandigheden, hetgeen prijsstarheid in de hand werkt. Derhalve zal hun handelen over het algemeen niet in overeenstemming zijn met marktevenwicht. Het feit dat er wordt gehandeld tegen niet-evenwichtsprijzen betekent dat niet iedereen zijn notionele vraag of aanbod kan realiseren: er blijft altijd iemand onvrijwillig achter met een onvervulde vraag of aanbod. Op deze wijze kan bijv. onvrijwillige werkloosheid worden werklaard die optreedt bij een tekortschietende vraag op de goederenmarkt. Beide onevenwichtigheden kunnen worden weggenomen door een vraagstimulerend overheidsoptreden. Dit is de tweede versie van Keynesianisme die Coddington onderscheidt, en die hij aanduidt met hernieuwd reductionisme. ${ }^{31}$

Men ziet hoe op deze manier fundamentele verschillen in visie op het functioneren van markten en daarmee samenhangend de verwachtingen die representatieve subjecten hebben, ten grondslag worden gelegd aan de onevenwichtigheidsanalyse en de Nieuw-Klassieke analyse. Het is niet mijn bedoeling om hier beide richtingen verder uitgebreid te behandelen. ${ }^{32}$ Waar het mij om gaat is de vrag waarom men in beide gevallen streeft naar een zgn. micro-economische onderbouwing van de macro-economie. En, daarmee samenhangend, de vraag waarom men in beide gevallen een weg kiest die leidt naar het reductionisme en de Hicksiaanse benadering. Want, kenmerkend voor deze micro-economische onderbouwing van de macroeconomie is immers dat wordt uitgegaan wan een representatief economisch subject dat handelt volgens het keuzetheoretisch uitgangspunt.

Ik denk dat men het antwoord op deze vrag moet zoeken in het streven natar een warlijk algemene economische theorie. Daarmee bedoel ik een

"2 Zie Coddingtor, (1983), pp. 105 e.v.

32 Een richting warin de discussie tussen beide stromingen zich than beweegt is het steeds verder uitwerken van de veronderstellingen voor het optreden vari het representatieve subject. Zo word in de onevenwichtigheidsanalyge de vrag gesteld hoe en op welke termijn prijzen zich wel anpassen an marktomstandigheden en hoe representateve subjecten zich verwachtingen vormen over toekomstige prijzen. 
theorie die in stat is om de volgende twee gestileerde feiten gelliktijdig te verklaren. ${ }^{37}$ Ten eerste het feit dat op veel markten het prijsmechanisme voor een redelijke totstandkoming van het evenwicht zorgt - laat ik dit het Walrasiaanse feit noemen. Ten tweede het feit dat langdurige werkloosheid mogelijk is, zonder dat zich tegelijkertijd op vele goederenmarkten sterke onevenwichtigheden woordoen - laat ik dit het Keynesiaanse feit noemen. Terwijl de Keynesiaanse theorie zich in eerste instantie richtte op het verklaren van het Keynesiaanse feit, richtte de algemene evenwichtstheorie zich op het verklaren van het Walrasiaanse feit. Men kan echter stellen dat tegenwoordig beide theorieèn in de gedaantes van resp. de algemene onevenwichtigheidsanalyse en de Nieuw-Klassieke benadering trachten vanuit hun verschillende achtergronden beide feiten simultaan te verklaren. Maar waarom kiezen beide stromingen daarbij als uitgangspunt de algemene evenwichtsanalyse, waarin Hicksiaanse representatieve subjecten handelen volgens het keuzetheoretisch paradigma? Hutchison behandelt dit probleem, zij het op zeer indirecte wijze, in zijn artikel The Limitations of General Theories in Macro Economics, de beperkingen van algemene theorieën in de macro-economie. Kenmerkend voor de teneur van zijn artikel is het volgende citaat: "Algemene theorieën vereisen algemene wetmatigheden, of zeer betrouwbare generalisaties, als uitgangspunt. Over het algemeen gesproken zijn er voor het grootste deel van de afgelopen tweehonderd jaren meer van dergelijke substantiële algemene veronderstellingen geweest die ten grondslag liggen aan de micro-economie dan aan de macro-economie... De veel sterkere meningsverschillen over de macro-economische politiek vloeien voort uit een veel ernstiger gebrek aan algemeen aanvaarde en vaste uitgangspunten waar de macroeconomische theorie op berust'. ${ }^{34}$ Als het de macro-economie ontbreekt aan duidelijke, algemeen aanvaarde uitgangspunten en de micro-cconomie kent deze uitgangspunten wel, wat ligt dan meer voor de hand dan te proberen om de macro-economie ook te baseren op de uitgangspunten van de micro-economie. $\mathrm{Nu}$ is het keuzetheoretische uitgangspunt binnen de micro-economie een zeer vruchtbaar uitgangspunt gebleken en - zoals ik al eerder heb gesteld - de Hicksizanse benadering in de vorm van reductio-

3 Het begrip gestileerde feiten roept problemen op die vergelikbuar ajn met het begrip representatief individu: het gat hier om ontwikelingen die in grote hin geschetst, zich op brede schal voordoen. Sinds het midden van de jaren zewentig bijw. is de werkloosheid in de West-Europese landen sterk loegenomen. Individuele tegenvootbeelden (bijw. Z Witserland); weerleggen een dergelik "feit" niet. Men realisere zich overigens dat het begrip "algemenc" theorie in dit verband niet inhoud da wordt gestreefd natar een model met gegeven paraneterwarden, dat geldt ongeracht tijd en plats.

34 Hutchison (1981), p. 257. 
nisme wordt veelal gezien als een goede mogelijkheid om via het representatieve subject een verbinding te leggen tussen het keuzetheoretische uitgangspunt en marktwerschijnselen. Uit dien hoofde is het dan ook niet verwonderlijk dat men probeert een algemene theorie te ontwikkelen op basis van het representatieve subject dat handelt wolgens het keuzetheoretische uitgangspunt.

\section{De doos van Pandora}

Mijn bezwaar tegen het al dan niet hernieuwde reductionisme komt overeen met de kritische kanttekeningen die Frank Hahn, een der groten wan de algemene evenwichtsanalyse, zelf bij deze analyse plaatst: 'Ik heb de algemene evenwichtsanalyse altijd beschouwd als iets dat lijkt op een modelvliegtuigje dat een whiegtuigbouwkundig ingenieur misschien bouwt. Mijn verbazing in recente jaren is dan ook erg groot geweest te ontdekken dat veel economen het modelvliegtuigje beschouwen als een luchtwaardig viegtuig ... terwijl theoretici over de hele wereld zich bewust zijn dat alles dat op dit modelletje wordt gebaseerd waarschijnlijk nooit kan vliegen, omdat het enkele wezenlijke aspecten van de wereld negeert ... in het bijzonder heeft het modelletje nooit aangegeven hoe de onzichtbare hand feitelijk werkt". "3s De vraag hoe economische activiteiten worden gecoördineerd is inderdaad een van de wezenlijke vragen uit de micro-economische onderbouwing van de macro-economie. En ik denk dat het hernieuwd reductionisme daarop geen antwoord kan geven: het reduceert immers het marktgebeuren tot een representatief subject en gaat daarmee voorbij aan de verscheidenheid van individuen wier activiteiten moeten worden gecoördineerd.

Dat er toch een spanning is tussen de verscheidenheid van individuen enerzijds en het representatieve subject anderzijds komt ook naar voren in het hierboven gegeven citaat van Hicks als hij enerzijds stelt dat de theorie "...is gepresenteerd - zoals die ook moet worden gepresenteerd - als een middel watarmee we soms kunnen vertellen of het gedrag van een bepaalde consument wel of niet consistent was met de veronderstellingen dat...' en anderzijds stelt "...de veronderstelling dat een bepaald persoon ... feitelijk zo handelt verdient geen ogenblik ook maar enige aandacht". "Wa "Wrom moet de theorie worden gepresenteerd in termen van een herkenbaar individu? Ik kan dat alleen begrijpen als een beroep op intuitieve plausibiliteit dat tevens noodt tot enige introspectie, conform de traditie van het apriorisme. Maar waarom is het dan volstrekt oninteressant of dat individu

3. Hatin (1981), pp, 1036-1039. Hij zegt overigens hetzelfde van de Keynesiananse theorie.

H $Z$ ie noot 4 , cursivering mijnerzijds. 
ook handelt in overeenstemming met de veronderstelling? Vermoedelijk ligt hieraan de gedachte ten grondslag dat individueel gedrag op toevallige en dus oninteressante - gronden afwijkt van het veronderstelde gedrag. maar dat in het gedrag van een groep, of statistisch gemiddelde, deze toevallige oorzaken tegen elkarar wegvallen. Echter deze gedachte roept enorme analytische en conceptuele problemen op, en is dan ook nauwelijks uitgewerkt. ${ }^{3 .}$ Een probleem waarop ik in dit verband wil wijzen is dat individuen elkaar in hun gedrag zullen beinvloeden. Dit kan er toe leiden dat een 'toevallig' gedrag van een individu het gedrag van een ander individu beïnloedt op een wijze die dan niet meer toevallig is. Men kan dan niet meer veronderstellen dat in groepsgedrag toevallige afwijkingen in individueel gedrag elkaar neutraliseren. ${ }^{38}$

Dit is een van de redenen waarom de neo-Oostenrijkers de macroeconomie en het reductionisme wantrouwen. Zo stelt bijv. Lachmann: "Macro-economisch evenwicht ... is een veel problematischer begrip dan marktevenwicht. Evenwicht van het individu, huishouding of onderneming, is een veel eenvoudiger notie dan beide (macro- en marktevenwicht, J.M.) en is nagenoeg synoniem met rationeel handelen ... We moeten niet vergeten dat als wij vertrekken uit de sfeer van acties die door én geest worden beheerst, in een huishouding of onderneming, naar de sfeer van acties waarin diverse geesten met elkaar rekening moeten houden terwijl ieder zijn eigen belang nastreeft, als in een markt, we met een enorm scala van problemen worden geconfronteerd waarvan maar al te veel economen in een gelukzalige onwetendheid verkeren. Het plaatsen van een probleem in een algemene evenwichtscontext moet betekenen dat men vertrouwen stelt in de overweldigende kracht van evenwichtstendenties..., 39 '... maar er zijn ook evenwichtverstorende krachten die ontstaan door onverwachte veranderingen. In veel gevallen zullen deze laatste de evenwichtstendenties overwinnen'. "Het wantrouwen tegen de macromeconomische analyse en het reductionisme dat uit bovenstaande citaten spreekt wordt enerzijds ingegeven door de neo-Oostenrijkse filosofie van het methodologisch indiwidualisme: het individu en de interactie tussen individuen staan centraal in

37 Een probleem wavaan in dit werband ten onrechte weinig andach wordt geschonken is het aggregatieprobleem. Daarbij is het merkwardig dat het aggregatieproblem walk wordt beschouwd als een formeel probleem, dat losstat wan conceptuele problemen, zonts ik die in het vervolg wan mijn betoog schets. Beide problemen zijn met enige moeite wellicht te onderscheiden, mar zeker niet analytisch te scheiden in die zir dalt men beide problemen onahankelijk van elkar zou kumneri oplossen.

Z Zie bijv. Shand (1984), p. 27. Zie ook Streissler (1977).

34 Lachmann $(1973)$, p. 16.

40 Lachmann (1973), p. 43. 
het neo-Oostenrijkse denken. Anderzijds vloeit dit wantrouwen voort uit het optreden van onzekerheden, wat het onderkennen van stabiele economische relaties bemoeilijkt.

Dit latste punt staat ook centraal in het reeds hierboven genoemde artikel wan Hutchison, warin hij de beperkingen van algemene theorieen in de macro-economie bespreekt. Terwijl de micro-economie een grote Wucht heeft kunnen nemen omdat zij weronderstelt dat de omgeving en de tockomst door alle subjecten goed worden gekend, kan de macro-economie zich hier niet op baseren. ${ }^{4}$ Naar Hutchison's mening moet de macroeconomie er rekening mee houden dat verwachtingen van subjecten niet wit kunnen komen: 'Keynes benadrukte dat zijn General Theory moest worden gebaseerd op veronderstellingen over foutieve verwachtingen'. "42 Maar dat geeft meteen de beperking aan van de mogelijkheid van algemene theorievorming in de macro-economie: "Met betrekking tot onwetendheid en foutieve verwachtingen kan men geen algemene wetmatigheden geven, alleen globale patronen en trends, die zeker kunnen veranderen met historische en institutionele veranderingen" " ${ }^{33}$ Macro-economische theorieern zijn daarom altijd tijd-en plaatsgebonden van arard. ${ }^{44}$

Men kan dit argument echter ook omkeren. Net als Coddington het hernieuwd reductionisme ziet als een mogelijkheid om de beperkingen van de Keynesiaanse gedachtengang te onderzoeken, kan men de Keynesiaanse macro-economie zien als een mogelijkheid om de beperkingen van het al dan niet hernieuwd reductionisme te onderzoeken. Deze gedachtengang is kenmerkend voor de post-Keynesiaanse benadering. Dit is tevens de derde versie van Keynesianisme die Coddington onderscheidt en die hij aanduidt met fundamentalisme. ${ }^{45} \mathrm{Hij}$ geeft dit als volgt weer: "Tegenover de duidelijk omschreven en stabiele doelstellingen en beperkingen die nodig zijn in de reductionistische the orievorming, benadrukt Keynes de basis van keuze in vage, onzekere en veranderende gebeurtenissen en omstandighe-

4i Zo stelt Hutchison (1981, p. 238) enigszins overdreven '... microweconomie ging over weten en macro-conomie over onwetendheid". Mar ook Cokdington (1983, p. 93) stelt dat: -...stabiele doelstellngen en duidelijk onaschreven beperkingen nodig zign om een voldoende sterke basis we kgen woor de makthearie".

${ }^{2}$ Hutchison (1981), p. 246. Voor een genuancecrie wisie dastop ze Kregel (1976)

4 Hutchison (1981), p. 246.

whet ar u niet verbazen dat Hutchison voor algemene theorievorming nog het neeste verwach van de theorie van de rationele verwachtingen. 'Onder sommige institutionetle omstandigheden en een bepald klimat wan verwachtingen zou de rationele verwachingen hypothese zels ean redehike benadering zijn. Mar het lijk een te sterke vereenvoudiging te vertegenwoordigen om als de onderbouwing van cen algemene macro-econorische theorie te dienen". (p. 257$)$.

45 Coddington (1983), pp. 93. e.*. 
den... ${ }^{46}$ Maar het gevolg is dat het fundamentalisme zelf "...geen waststaand mechanisme aangeeft volgens welke gebeurtenissen zich ontvouwen; maar het laat zien hoe men over deze gebeurtenissen zou kunnen verhalen'. ${ }^{47}$ Coddington concludeert: 'Fundamentalisten onderscheiden zich derhalve niet primair door de veronderstellingen die zij hanteren, maar door hun houding daartegenover ... (het) ontbreekt fundamentalisme aan intellectuele autonomie... .48

Nu maakt Coddington zich wel erg makkelijk van het fundamentalisme af. ${ }^{49}$ Men moet bereid zijn zich af te vragen enerzijds onder welke omstandigheden, '...welke soorten onwetendheid en onjuiste verwachtingen zich voordoen; en wanneer nu, anderzijds min of meer toereikende kennis, en evenwichtsherstellende krachten, zich warschijnlijk zullen voordoen'. ${ }^{50}$ Maar dan geeft men ook aan welke ruimte er is voor reductionisme, al dan niet in hernieuwde vorm, oftewel welke ruimte er is voor de Hicksiaanse benadering.

Impliciet veronderstelt de Hicksiaanse benadering dat individuen handelen volgens duidelijk omschreven en stabiele doelstellingen en nevenvoorwaarden - dit geldt dus ook voor hun verwachtingen. ${ }^{51} \mathrm{Bij}$ de formulering van veronderstellingen hierover wordt enig beroep gedaan op plausibiliteit en introspectie. Dat men vervolgens dit handelen ook kan toeschrijven aan een Hicksiaans representatief subject, veronderstelt impliciet dat individuen elkaar niet sterk beinvloeden in hun optreden. Dit hangt samen met de sterke oriëntatie van de Hicksiaanse benadering op evenwichtssituaties, in de zin van rusttoestanden. ${ }^{52}$ Als een proces is uitgekristalliseerd tot een evenwichtssituatie, beinvloeden die individuen elkaar alleen op een gekende en stabiele wijze: de evenwichtssituatie kan dan worden beschreven in termen van een Hicksiaans respresentatief subject.

\section{De Marshalliaanse benadering}

Ik ben mijn betoog begonnen met de vraagstelling in hoeverre een zinvolle micro-economische onderbouwing van de macro-economie mogelijk is en

4 Coddington (1983), p. 95 .

47 Coddington (1983), p. 99.

48. Coddington (1983), pp. 117-118.

4y Voor een stellige kritiek thierop, zie Snippe (1985b).

34. Hutchison (1978), p. 211.

5. Zie de verwijzing nat Coddington in noot 41

52. Dit geldt dus ook voor de zgn. onevenwichtigheidsanalyse. Men noet hichlyij wen onderscheid maken tussen markievenwicht - dat word hier niet alleen bedoeld - en evenwich in de zin van een situatie waarn een econome durzaam kan verkeren, zonder dat or inherente tendenties tof verandering zijn, korthalve angeduid met rustloestand zie verdet bijv. Benassy (1982), p. 3 . 
op welke wijze de notie van een representatief economisch subject hierbij een rol speelt. Daarbij heb ik aangegeven dat het begrip representatief economisch subject op twee manieren kan worden geinterpreteerd: Hicksiaans en Marshalliaans, waarbij de eerste interpretatie algemeen is gevolgd in de economische theorie na de Tweede Wereldoorlog. Waarschijnlijk heeft in het voorgaande echter al doorgeklonken dat ik bewijfel of er veel mogelijkheden zijn voor een zinvolle toepassing van de Hicksiaanse benadering in de economische theorie. De vraag is dan of dit eveneens geldt voor de Marshalliaanse benadering.

Deze vraag is ook vanuit een Maastrichtse optiek interessant. Om dat toe te lichten breng ik $u$ in herinnering dat de Hicksiaanse benadering wordt gekenmerkt door het keuzetheoretisch uitgangspunt toe te passen op een Hicksiaans representatief subject, gebruikmakend van de axiomatischdeductieve methode. De Marshalliaanse benadering lijkt daarentegen meer inductief van aard: men poogt immers op basis van zorgvuldig waarnemen tot generalisaties te komen, ${ }^{5,3}$

Elders hebben Hein Schreuder en ik uitwoerig andacht besteed aan de verschillen in wetenschapsbeoefening tegen de achtergrond van verschillen tussen de algemene en de bedrijfseconomie. ${ }^{54} \mathrm{Ik}$ wil dan ook niet verder stilstaan bij de methodologische verschillen. Deze verschillen zijn al zo oud als de economische wetenschap zelf, zo niet ouder, en zullen steeds blijven bestaan - hetgeen overigens zeer vruchtbaar is. Wel wil ik er op wijzen dat Hein Schreuder en ik hebben geconcludeerd dat bedrijfseconomie meer inductief van aard is en algemene economie meer deductief. Dit laatste is in overeenstemming met de dominante traditie binnen de algemene economie van de Hicksiaanse benadering. Men kan zich nu afvragen of een samenwerking met de bedrijfseconomie de algemene economie dan uitnodigt tot het overstappen naar de meer inductieve Marshalliaanse benadering - en in hoeverre dat wenselijk is.

Een probleem bij de beantwoording van deze vraag is dat het niet duidelijk is wat de Marshalliaanse benadering inhoudt. Ik heb hierboven als enige kenmerk gegeven dat men poogt door zorgvuldige waarnemingen te komen tol generalisaties, maar wel op een zodanige wijze dat de veronderstellingen waartoe deze leiden herkenbaar blijven in relatie to het waarnemingsmateriaal. Opmerkelijk is nu dat Hutchison in deze richting denkt bij zijn bespreking van de beperkingen van algemene theorieèn in de

3) De ard wan het wannemen leidt tevens tot een belangrijk werschil met hel apriorisme, dat vakk in de Hicksianse benadering wordt gevolgd. Tenwill dit apriorisme sterk uitgat van intuithwe kennis en introspectic, steunt de Marshalliaanse bendering siterb op empirische warnemingen.

s. Zic Muyshen en Schrouder (1985). 
macro-economie. Als men erkent dat verwachtingen niet wit kunnen kow men wordt men geconfronteerd met een groot probleem: 'Er is maar een manier waarop verwachtingen juist kunnen blijken te zijn, maar een oneindig aantal mogelijke manieren waarop zij, meer of minder ernstig, fout kunnen gaan. Deze onvermijdelijke conclusie heeft methodologische consequenties, want het is misschien alleen mogelijk de variëteit aan mogelijkheden te bestuderen aan de hand van casestudies" 5 "Kortom, de veronderstellingen moeten dan in ieder geval herkenbaar blijwen in relatie tot het waarnemingsmateriaal. En Hutchison citeert met instemming Herbert Simon die stelt dat de acceptatie van onwetendheid en onzekerheid: '...een principiële verandering in wetenschappelijke stijl vereist, van een nadruk op deductief redeneren binnen een strak schema van axioma's naar een nadruk op een gedetailleerde empirische verkenning van complexe gedachtenketens. Op steeds breder wordende terreinen van de economische wetenschap zullen de te sterk vereenvoudigende veronderstellingen van de door zijn omgeving beperkte alleswetende beslisser worden vervangen door een realistische (en psychologische) karakterisering van de begrenzingen van de rationaliteit van de Mens, en de gevolgen van die begrenzingen voor zijn economische gedrag'. ${ }^{56}$ Deze nadruk op een gedetailleerde empirische verkenning van menselijk handelen en de behoefte aan 'realistische' veronderstellingen lijkt mij duidelijk te passen in een Marshalliaanse benadering. 57

Op deze wijze geinterpreteerd kan zonder enige twijfel worden gesteld dat een samenwerking met de bedrijfseconomie duidelijk de algemene economie uitnodigt om de dominante traditie van de Hicksianse benadering in te ruilen voor de Marshalliaanse benadering. Want in wezen volgt de bedrijfseconomie de Marshalliaanse benadering. Wellicht ten overvloede, ${ }^{58}$ citeer ik het in Nederland gezaghebbende leerboek over de bcdrijfseconomie van Bouma: 'De toepassing van de deductief-nomologische verklaring in de bedrijfseconomie ligt niet voor de hand, omdat in dit vak nog geen algemene wetten hebben stand gehouden ... Zo heeft men het

35. Hutchison (1982), p. 253 .

56 Zowel Hutchison (1982), p. 253 als Hutchison (1978), p. 211. Hij citeert Simon (1976), pp. 147-148. In hoeverte men overigens met het begrip begrensde rationditeit de doos van Pandora opent, hangt af van de mate warmee men dan alstand neemt van het keuzetheore. tisch uitgangspunt.

57 Deze wisie vertoont zeer nauwe verwantschap met de opvattingen van woor-oorlogse auteurs als Von Mises en Robbins, met als belangrijk verschil het in noot 53 genoemde verschi in warnemingsmethoden. Von Mises en Robbins zijn immers duidelijk aprioristen. Oyeri. gens liggen hier ook mogelijh heder voor samenwerking met de (overige) gedrags-en matschappijwetenschappen, conform de bedoelingen warmee deze faculteit is opgencht.

58. Dit komt namelijk al duidelijk naar voren in Muysken en Schreuder (1985). 
'geloof' in de wetmatigheid wan het economisch handelen moeten prijsgeven .... $U$ zilet dat dit volledig in het verlengde ligt van de gedachtengang van Hutchison. Het zal u niet verwonderen dat Bouma stelt over rationeel handelen: '... de inhoud van dit begrip is afhankelijk van de mate van voorkennis (zekerheid; onzekerheid) waarover het kiezende subject beschikt, alsmede van de complexiteit van de probleemstelling in verhouding. tot het menselijk en/of machinaal reken- en redeneervermogen dat het betrokken subject ten dienste staat ... Het aldus gerelativeerde begrip 'begrensde rationaliteit' kan slechts op inductief-statistische wijze worden beschreven en verklaard', ${ }^{\circ}$

\section{De samenwerking met de bedrijfseconomie}

Het lijkt erop dat dit betoog onontkoombaar naar één conclusie leidt, die ook een mooi besluit zou zijn van deze oratie. Zo eenvoudig liggen de zaken helaas echter niet. De bedrijfseconomie kan en wil geen volwaardig alternatief bieden voor de Hicksiaanse benadering: zij pretendeert geen waarlijk algemene economische theorie te geven in de hierboven omschreven zin. En zij geeft geen antwoord op de vraag hoe economische activiteiten in een volkshuishouding worden gecoördineerd - ofschoon Hein Schreuder in zijn oratie wel laat zien dat op het gebied van de coördinatie van economische activiteit de algemene en de bedrijfseconomie in hun theorievorming elkaar sterk naderen. Maar de bedrijfseconomie poogt aan te geven hoe bedrijven zich onder verschillende omstandigheden gedragen, overwegend gebaseerd op de Marshalliaanse benadering. Daarmee kan zij dan een zeer belangrijke bijdrage leveren aan de mogelijkheid tot een micro-economische onderbouwing van de macro-economie. Echter deze bijdrage zal moeten worden ingebed in een theorie over hoe economische activiteiten in een volkshuishouding worden gecoördineerd.

Hierboven heb ik al aangegeven dat ik de Hicksiaanse benadering daar minder geschikt woor acht. Tegenover die benadering presenteren de postKeynesianen en de neo-Oostenrijkers hun alternatieven. Beide stromingen schenken daarbij veel aandacht aan het ondernemersgedrag. In de neoOostenrijkse benadering stat de dynamische ondernemer, de "entrepreneur" centraal. Door voortdurend naar gaten in de markt te zoeken en zijn kansen zo goed mogelijk te benutten is de ondernemer de drijvende kracht achter het economische proces. ${ }^{61}$ De post-Keynesianen stellen de rol van investeringen en het optreden van grote ondernemingen centraal in hum

59 Bouma (1982), p. 254

6) Bomma (1982), pp. 285.286. Zie ook thet herbowen gegeven citaat van Simon.

61 Zic bijw. Shand (1984). 
analyse. Zij onderschrijven ook de dynamische visie op mededinging: $\therefore$...rivaliteit tussen de gevestigde ondernemingen in een industrie behoeft alleen maar voldoende te zijn om er voor te zorgen dat er geen winstge vende investeringsmogelijkheden over het hoofd worden gezien". ${ }^{62} \mathrm{Maar}$, uit het voorgaande is gebleken dat alhoewel zij allebei de Hicksiaanse benadering verwerpen, de post-Keynesiaanse en de neo-Oostenrijkse benadering ook op bellangrijke punten werschillen. ${ }^{63}$ Een van die punten is hun houding tegenover de macro-economie. De neo-Oostenrijkers kiezen als vertrekpunt voor hun analyse de micro-economie - zij het een zeer dynamische en turbulente micro-economie - en zijn zeer sceptisch over de mogelijkheid om daaruit stabiele relaties op macro-niveau af te kunnen leiden. Daarnaast ontkennen zij dat een macro-economische omgeving beperkingen kan stellen aan het handelen van individuen. Deze punten vloeien voort uit hun methodologische individualisme. De post-Keynesianen kiezen daarentegen de macro-economische analyse als vertrekpunt van hun analyse en zoeken via de Marshalliaanse benadering een micro-economische onderbouwing daarvoor ${ }^{64}$ Hun macro-economische analyse wordt echter niet zonder meer gekenmerkt door stabiele relaties, dit hangt met name af van '...de sitwatie met betrekking tot de algemene verwachtingen of de verwachtingen op lange termijn'.65

${ }^{62}$ Kenyon $(1979)$, p. 37.

63. Zie voor fundamentele discussie hierover $\mathbb{K}$ regel (1985)

64 Kregel (1985) citeert hier mert instemming Pareto: "Allhoewel Pareto bevestigt dat absracte theorie alleen kan worden boordeeld met betrekking tot 'algemene en gemiddelde feiten, niet toevallige gebeurtenissen", benadrukt hij voorts dat "de classificatie van verschijnselen als primair en secundair (meer en minder algemeen)... is niet hetzelfde vanut het algemene gezichtspunt van de wetenschap en vanuit het bijzondere gezichtspunt varn een individu..." Pareto stelt derhalve niet dat de theorie het totstandkomen van individuele beslissingen moet negeren. De specificatie van de lange-termijn voorwaarden (voor een theorie van de effectieve vraag, J.M.) op het niveau dat Pareto 'primair' noemt moet ook worden uitgebreid tot een analyse van individueel gedrag..." (pp. 18, 19). Zie ook Eichner (1976) die in zijn 'Megacorp' zoekt naar een micromeconomische onderbouwing van macro-economische dynamische processen. Hij kiest als uitgangspunt van zijn analyse een representatieve onderne. ming in de vorm van de megacorp, die verschillende karakteristieken heeft. 'De megacorp kan worden getypeerd door de ondernemingen die behoren tot de grootste 500 ondernemingen uil Fortune Magazine"s jaarliks overzich" ( $p$. 19). "Natuurlijk zullen in de werkelijkheid, zelfs ... bij de gromtste 500 ondernemingen, deze kargkteristieken niet worden wargenomen, in hun volledigheid, in alle gevallen. In die zin wertegenwoordigt thet beeld wan de megacorp dat is geschetst een ideaal of zuiver type ... maar, op basis van het beschikbare waarnemingsmateriaal kom de megacorp dichter bij een wergave van de feitelijke situatie in de oligopolistische sector van de Amerikasuse economie" (p. 45).

6regel $(1976, p .214)$. In dit artikel geeft Kregel aan hoe de post-Keynesianen ongekerheid en verwachtingen in hun analyse introduceren, zonder daarbij hun analyse onhanteerbat te maken. Hij makt hiertoe een onderscheid tussen algemene, lange-termijn verwachtingen en 
Ten aanzien van dit laatste aspect ben ik geneigd nog iets verder te gaan dan de post-Keynesianse visie. De notie dat er, zij het met de nodige $k$ walificaties, stabiele relaties bestaan op macromeconomisch niveau is in het verleden zeer vruchtbaar gebleken. De recente discussies over de zin van econometrische modellenbouw kunnen weliswaar de stabiliteit van bepaalde relaties in twijfel trekken voor het huidige tijdsgewricht, men gat toch niet zo ver dat men de zin ontkent van het leggen van verbanden tussen geaggregeerde grootheden. ${ }^{66}$ Ook Hutchison, met al zijn twijfels aan algemene wetten in de macro-economie, doet dit niet.

Het probleem blijft dan om in het streven naar een waarlijk algemene economische theorie, de kloof tussen de macro-economie en de microeconomie te owerbruggen. En daarbij kunnen beide stromingen niet als volwaardige alternatieven voor de Hicksiaanse benadering worden beschouwd. Beiden hebben de moed om de 'doos van Pandora' te openen, ${ }^{67}$ door onvolledige kennis en onzekerheid in hun analyse te introduceren. Maar beide doen dan denken aan de tovenaarsleerling: de analytische en methodologische problemen die huit benadering oproept zijn nog lang niet opgelost en voortdurend in ontwikkeling.

Ik stuit dan ook op een probleem dat kan worden gekarakteriseerd door het oer-Nederlandse spreekwoord: 'Je moet geen oude schoenen weggooien voordat je nieuwe hebt". Ik heb hierboven de Hicksiaanse benadering van vraagtekens voorzien, van zoveel vraagtekens dat ik geneigd ben deze benadering te vergelijken met oude schoenen die beginnen te knellen. Maar wat zijn de nieuwe schoenen? De post-Keynesiaanse en neo-Oostenrijkse benaderingen kunnen nog niet als volwaardige alternatieven voor de Hicksiaanse benadering worden beschouwd: de nieuwe schoenen staan aantrekkelijk opgesteld in de etalage, maar je kunt ze nog niet passen ${ }^{69}$.

individuele, korte-termin verwactitingen. De analyse is hanteerbaar als da algemene, langeterminn verwachtingen constant worden verondersteld. Er zijn dan ook stabiele macroconomsiche relaties.

W Zie bijw. het overzicht van macro-economische modellenbouw van Den Butter (1984). warin hij het misverstand idat de micro-economische analyse dienst zou kunnen doen als wen vervanging van de macro-economie" uit de weg ruimt. Zie ook Pen (1984).

6. Deze term ontleent Hutchison $(1981$, p. 253) aan Patinkin.

Zie bijw. Kregel (1976) en Shand (1984).

69 Strikt gesproken gaat het hier niet om nieuwe schoenen, beide benaderingen hebben een rijke vour oorlogse traditie. Het gaat veeteer om oude modelletjes die weer in de mode raken; dit geldt met name woor de neo-Oostenrijkse benadering. 
Tenslotte is het gewaarlijk om de Hicksiaanse benadering te vergelijken met oude schoenen die op een gegeven ogenblik onvermijdelijk helemaal versleten zullen zijn. Wat dat betreft heeft deze benadering een opmerkelijke flexibiliteit getoond om tegemoet te komen aan kritiek.

Toch is het duidelijk dat ik in ieder geval op zoek ben naar nieuwe schoenen. En bij dat zoekproces zie ik duidelijke mogelijkheden om met de bedrijfseconomen samen te werken om de vruchtbaarheid van de Marshalliaanse benadering woor de economische theorie te onderzoeken. Uit deze samenwerking hoop ik met name te leren hoe men beheerst de 'doos van Pandora' kan openen, als men onvolledige kennis en onzekerheid in de analyse introduceert. Bedrijfseconomen hebben in theorie en praktijk hier al veel eerder oog voor gehad dan algemeen-economen: ik hoop veel van hen te kunmen leren. Hein Schreuder zal in zijn oratie wat dat betreft een voorproefje geven.

\section{Tot besluit}

Tenslotte hecht ik eraan mij te richten tot diegenen onder u die dit betoog met enige verbijstering hebben gevolgd. Ik kan mij voorstellen dat sommigen onder u denken: waar praat die man over, wat heeft dit nu nog met economie te maken? Tot hen zou ik willen zeggen: het heeft alles met economie te maken. Uitspraken die economen doen over economisch politieke kwesties en de adviezen die zij geven, zijn onlosmakelijk verbonden met de inzichten die ik hierboven heb besproken. En als men deze inzichten ter discussie stelt, stelt men ook de uitspraken en adviezen ter discussie. Dat is een taak van de economische wetenschap. Dit neemt niet weg dat men natuorlijk ook de taak heeft om op een gegeven ogenblik naar beste weten adviezen te geven. Alleen, het huidige 'beste weten' kan hopelijk nog beter worden. En hier ligt de voornaamste taak van de economische wetenschap.

Ik ben mijn oratie begonnen met de vraag te stellen in hoeverre een zinvolle micro-economische onderbouwing van de macro-economie mogelijk is en in welke mate en op welke wijze de notie van een representatief economisch subject daarbij dienstig kan zijn. Het zal hopelijk niemand verbazen dat ik deze vraag niet volledig heb kunnen beantwoorden, want het is een ingewikkelde vraag waar economen al generaties lang mee worstelen en ongetwijfeld zullen blijwen worstelen. Deze vraagstelling is dan ook ongetwijfeld nog actueel als ik ooit een afscheidcollege zou mogen geven. Het ligt in mijn bedoeling bij die gelegenheid duidelijke vorderingen aan te kunnen geven, die het resultaat zijn van een vruchtbare samenwerking tussen de algemene en de bedrijfseconomie. 


\section{BLJLAGE: Het onderscheid tussen micro- en macro-economie}

Met de opkomst van de Keynesiaanse theorie, in het bijzonder de hydraulische versie, is binnen de economische theorie het onderscheid gegroeid tussen de micro-economie en de macro-economie. Een populaire manier om dit onderscheid aan te geven is dat de macro-economie zich bezighoudt met geaggregeerde grootheden, gedefinieerd op nationaal niveau, en de micro-economie zich bezighoudt met gedesaggregeerde grootheden, gedefinieerd op individueel niveau. Zonder de zin van dit onderscheid volledig te willen ontkennen, ligt de zaak niet zo eenvoudig. Het hierboven beschreven onderzoek van de theorie van het consumentengedrag is bijv. een typisch micro-economisch onderzoek, terwijl daarin de consumptieve bestedingen in een land worden bestudeerd naar bijv, drie zeer geaggregeerde goederencategorieën: duurzame consumptiegoederen, niet-duurzame consumptiegoederen en diensten. Het onderzoek is dan niet zozeer micro-economisch van aard omdat niet éên maar drie goederen in een land worden onderscheiden, maar veeleer omdat het onderzoek duidelijk een toepassing van het keuzetheoretisch paradigma betreft.

Dit brengt mij bij een ander aspect van het onderscheid tussen de microen de macro-economie, namelijk het uitgangspunt van waruit men redeneert. Vanuit die optiek is het hydraulicisme typerend voor de macroeconomie en de Hicksiaanse benadering, in het bijzonder het zich baseren op het keuzetheoretisch paradigma, typerend voor de micro-economie. Weintraub deelt bijy. deze opvatting. Hij gaat zelfs nog iets verder als hij de micro-economie en de macro-economie presenteert als twee strijdende onderzoekprogramma's, resp. het neo-Walrasiaanse en het Keynesiaanse onderzoekprogramma. ${ }^{76}$

Een van de gevaren van dit laatste onderscheid is echter dat de gedachte post zou kunnen vatten dat de micro-en de macro-economie concurrerende theoretische kaders zijn die verschillende antwoorden geven op gelijke vragen. Dit is echter maar zeer ten dele waar. Zo stelt Blaug bijv. in zijn overzicht van de geschiedenis van het economische denken: "...bijna geen econoom hield zich na 1870 bezig met het soort macro-economische problemen waarmee Keynes bezig was. De kracht van de neo-klassieke theorie lag in de micro-economische analyse, die zich slecht leende voor een bespreking van oplossingen voor algemene werkloosheid' "Nu is het op

70 Weintraub $(1979)$, p. 16.

7 Blavg (1968), p. 662 . 
zich juist dat de micro-economic zich traditioneel bezighoudt met vraagstukken op het terrein van allocatie en de werking van markten. Dit zijn terreinen waar de macro-economie weinig aandacht aan heeft besteed. Traditioneel houdt zij zich bezig met vraagstukken rond de geld theorie en de conjunctuur-, groei- en verdelingstheorie, vraagstukken waaraan de micro-economie na de Tweede Wereldoorlog weinig aandacht placht te schenken. ${ }^{72}$ Hier begint echter verandering in te komen. Steeds meer begint men, evenals in de periode rond de jaren dertig, oog te krijgen voor de wisselwerking tussen allocatieproblemen en de werking van markten enerzijds en problemen van conjunctuur, groei en verdeling anderzijds, een wisselwerking waarin in de ogen van sommigen het geld juist een centrale rol speelt.

\section{Literatuur}

Barten, A.P., Theorie en empirie van een volledig stelsel van waagvergelijkingen, Dissartatic, Den Haag, 1966.

Barten, A.P., The Systems of Consumer Demand Functions Approach: A Review, Econometrica, Vol. 45, 1977, pp. 23-53.

Blaug, M., Economic Theory in Retrospect, Heinemann, Londen, 1968.

Blaug, M., The Methodology of Economics, Cambridge University Press, Canbridge (UK), 1980 .

Bennasy, J.P., The Economics of Market Disequilibrium, Academic Press, New York, 1982

Bouma, J.Lin, Inleiding tot de bedrijfseconomie, Delwel, Wassenaar, 1982.

Butter, F.A.G. den, Macro-economische modelbouw: een terugbik en enige recente ontwikkelingen, Econowisch-Statistische Berichter. 1984, pp. 1140-1148.

Coddington, A., Keyrasian Economics: The Search for First Principles, Allen and Unwin, Londen, 1983.

Cross, R., The Duhem-Quine Thesis, Lakatos and the Appraisal of Theories in Macroeconomics, The Economic Jonurnal, Vol. 92, 1982, pp. 320 340.

Deaton, A.S., Models and Projections of Demand in Post-War Briain, Londen, 1975.

Eichner, A.S., The Megacorp \& Otgopoly, Shaipe, Armonk (N.Y.), 1976 (1982).

Eichner, A.S. (red.), A Guide to Post-Keynesian Economics, Sharte, White PL Lans (N.Y.), 1979 .

Grossman, H. 1., Why Does Aggregate Employment Fluchate?. American Economic Rewiew, Voll. 69, mei 1979, pp. 64-69.

Hahn, F.H. Rewiew of M. Beenstock: A Neoclassical Analysis of Macroeconomic Policy, The Economic Joumal, Vol. 91, 1981, pp. 1036\%1039.

Harcourt, G.C. (red.), The Microeconomic Fondanom of Macroeconomics, Macmillan, Londen, 1977.

Hicks, J.R.. A Revision of Demand Theory, Clarendon Press, Oxford, 1965.

72. Dit in tegenstelling to de situatie voor de Tweede Wereldoorlog. 
Hutchison. T.W., On Renolutions and Progress in Economic Knowledge, Cambridge Unwersicy Press, Cumbridge (UK). 1978.

Hutchison, T.W., The Politics and Philosophy of Economics, Basil Blackwell, Oxford, 1981. Kenyon, P. Pricing, in: Eichner (1979), op. 34-45.

Kamer, A. The New Classical Macrotconomics, Wheatsheat Books, Brighton, 1984.

Kregel, J. Economic Methodology in the Face of Uncertainty: The Modeling Methods of Keynes and the Post-Keynesians, The Economic Jownal, Vol. 86, 1976, pp. 209-225.

Krege: J., Conceptions of Equilhrium: The Logic of Choice and he Logic of Producrion, Matiuscript, 1985.

Lachman, L.M., Macromeconomic Thinking and the Market Economy, Hobart Paper 56. Institute of Economic Affairs, Londen, 1973.

Latsis, \$.J. (rea.). Method and Appraisal in Economics, Cambridge University Press, Cambridge (UK), 1976 .

Marshall, A. Principles of Economics, Eighth Edition, 1920, Reset and Reprinted, Macmillan. Londen, 1977.

Modigliani, F., The Monetarist Controversy or, Should we Forsake Stabilization Policies, American Economic Review. Vol. 69, 1977, pp. 1-9, geciteerd ait Korlias en Thorn. Modern Macroeconomics, 1979.

Muysken, J. an Schreuder, H., Economische wetenschappen: eenheid in verscheidenheid?, in: J. Muysken en $\mathrm{H}$. Schreuder (red.). Economische wetenschappen eenheld in verscheiderhetd?, Van Gorcum "Assen, 1985

Ng, Y-K. A Micro-macroeconomic Analyss based on a Representative Firm, Economica, Vol. 49, 1982, pp. 121-139.

Pen, J., Over het misleidende van de micro-economie, Hollands Maandblad, Vol 25, 1984, pp. 3.9

Shand, A.H., The Capialisy Alternatwe, Wheatshear Books, Brighton, 1984.

Simon, H., 'From Substantive to Procedural Rationality', in: Latsis (1976), pp. 109-128.

Snippe, J., Macroeconomic Adjusmen Processes: A Sieguential Analytical Approach, Dissertatie, Groningen, 1985 a.

Snippe, $J$. On the Scope of Hydraulic Economics: some reffections on Allan Coddington's Keyresian Economics Marnuscript, 19856.

Streissler, E., What Kind of Microeconomic Foundations of Macroeconomics are Necessary, in: Harcourt (1977), pp. 96-132.

Weintraub, E. R., Microfondations, Cambridge University Press, Cambridge (UK), 1979.

Weintraub, E.R., Joan Robinson"s Critique of Equilibrium: An Appraisal, American Economic Review, Vol. 75, mei 1985 , pp. 146-149. 